Volume 8. No. 4, April 2020

International Journal of Emerging Trends in Engineering Research

Available Online at http://www.warse.org/IJETER/static/pdf/file/ijeter52842020.pdf

https://doi.org/10.30534/ijeter/2020/52842020

\title{
Relative Density Effect on Shear Behaviour of Fibre-Flyash-Sand
}

\author{
Amin Chegenizadeh ${ }^{1}$, Mahdi Keramatikerman ${ }^{2}$, Hamid Nikraz ${ }^{3}$ \\ ${ }^{1}$ Senior Lecturer, Department of Civil Engineering, Curtin University of Technology, Kent Street, Bentley, Perth, \\ Western Australia 6102, Australia. amin.chegenizadeh@curtin.edu.au \\ 2 Engineer, Arup Australia, 61-73 Sturt Street, Suncorp Tower, Townsville QLD 4810, Australia. \\ mahdi.keramati@arup.com \\ ${ }^{3}$ Professor, Department of Civil Engineering, Curtin University of Technology, Kent Street, Bentley, Perth, \\ Western Australia 6102, Australia. h.nikraz@ curtin.edu.au
}

\begin{abstract}
Relative density is one of the important factor in sample preparation for running traixial tests. The issue of different relative density has been interest of many studies. This study focus on changes in Relative Density (Dr) This study aims to explore effect of three different Dr (i.e., 10\%, 40\%, 60\%) on peak shear strength extracted from triaxial tests. The mixture prepared as fibre, flyash and sand. Fiber dosage kept constant at $5 \%$. The flyash percentage were $10 \%, 15 \%$. The results showed that deviatoric stress was increased by increasing in Dr.
\end{abstract}

Key words: Relative Density, Shear, Fiber,Flyash

\section{INTRODUCTION}

Research on sand has been conducted in literature [1-6].Fiber is one of the materials being used in many civil engineering projects. Among those, in particular application of fiber in soil has been researched [7-21]. Application of by product and waste in different view such as shear and consolidation [22-47] has been studied in literature. The above literature all proved that there is a need to consider combination of flyash and fiber. Among those effective parameters, relative density is one of the important factors. Therefore, this study considers effect of flyash (FA) content on the behaviore of fa-Fiber mixture with sand. This study incorporates triaixal tests on the above mixtures. In Curtin university, the application of fiber in direct shear tests, triaxials, consolidation tests and compaction tests were conducted example $[8,10,12,14,17,19]$ and this study takes us further in usage of combination of by-product which again used in Curtin university example[22,34, 29,34,36 ]. Relative density (Dr) is an important parameter in preparation of a sample in geotechnical experimental study. In fact, relative density represents how close are soil particles and how loose or dense are sample. This parameter has a relation with void ratio in the loosest, densest and natural states of the soil. In general, a relative density in the range of 0 to $15 \%$ is categorized as a very loose, $15-35 \%$ is categorized as loose, $35-65 \%$ medium dense, $65-85 \%$ dense, and $85-100 \%$ very dense.

\section{MATERIALS}

The selection of materials was conducted to get the best outcome in accordance with subject of the study. The materials which was used: a) Sand b)Fiber c) Flyash

\subsection{Sand}

The sand was supplied from Perth's supplier. The sand had yellow color. The particle size distribution (PSD) can be found in Figure 1.

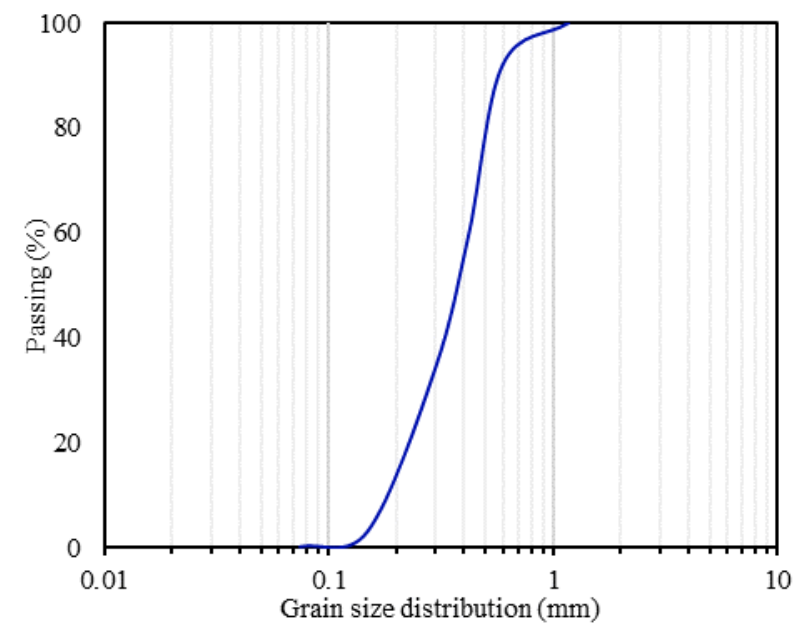

Figure 1: PSD of Sand

\subsection{Flyash}

Flyash(FA) properties can be found in Table 1 .

Table 1: Flyash Properties

\begin{tabular}{|l|l|}
\hline pH & 10 \\
\hline SG & 2 \\
\hline Color & Light gray \\
\hline
\end{tabular}




\subsection{Fibre}

Propylene fibre (PF) was used in this study with characteristics such as tensile moduli of $0.6 \mathrm{GPa}$ and a elongations at break in the range $92 \%$.

\section{TESTING PLAN}

Triaxial device was used to model the behavior of the mixture. The tests were conducted in three different confining pressure. The confining pressure were $100 \mathrm{kPa}, 150 \mathrm{kPa}$ and $200 \mathrm{kPa}$. The mixture as explained earlier was constructed in with 5\% fiber. The flyash also kept constant at $10 \%$. In this plan, Dr was changed from 10 to $60 \%$ to evaluate the effect of Dr. Table 2 presents the testing program.

Table 2: Testing program utilized in this study

\begin{tabular}{|l|c|c|c|c|}
\hline Sample ID & $\begin{array}{c}\text { Flyash } \\
(\%)\end{array}$ & Dr\% & $\begin{array}{c}\text { Fiber } \\
(\%)\end{array}$ & $\begin{array}{c}\text { Confining } \\
\text { pressure } \\
(\mathbf{k P a})\end{array}$ \\
\hline S-10FA-5F & 10 & $\begin{array}{c}10,40, \\
60\end{array}$ & 5 & $\begin{array}{c}100,150,20 \\
0\end{array}$ \\
\hline S-15FA-5F & 15 & $\begin{array}{c}10,40, \\
60\end{array}$ & 5 & $\begin{array}{c}100,150,20 \\
0\end{array}$ \\
\hline
\end{tabular}

\section{TEST RESULTS}

\subsection{Compaction Results}

Table 3 shows the compaction characteristics of the used mixture.

Table 3: Results of compaction tests

\begin{tabular}{|l|c|c|c|}
\hline Sample ID & FA (\%) & OMC (\%) & $\begin{array}{c}\text { MDD }\left(\mathbf{g r} / \mathrm{cm}^{\mathbf{3}}\right. \\
)\end{array}$ \\
\hline S-10FA-5F & 10 & 14.5 & 1.54 \\
\hline S-15FA-5F & 15 & 15.7 & 1.51 \\
\hline
\end{tabular}

\subsection{Triaxial Tests}

Triaxial device was used to investigate shear behavior. This test has three steps:
a) Saturation
b) Consolidation
c) Run the test

The sketch of the sample under pressure can be seen in Figure 2. The results can be seen in Figure 3 to 8 .

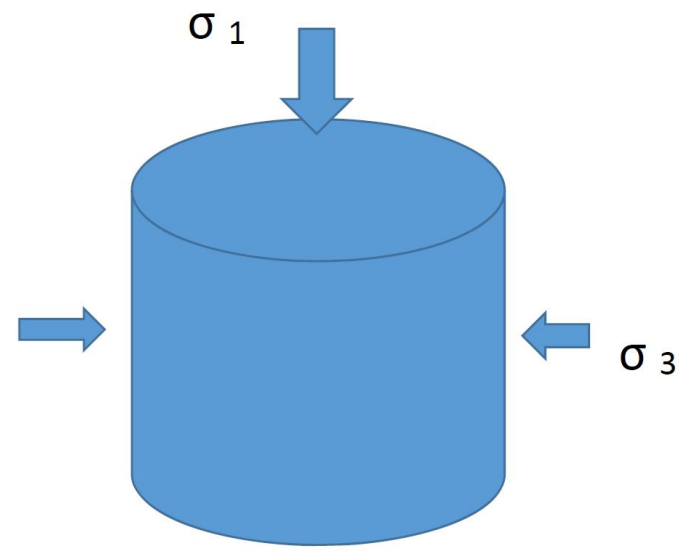

Figure 2: Triaxial Test Sketch

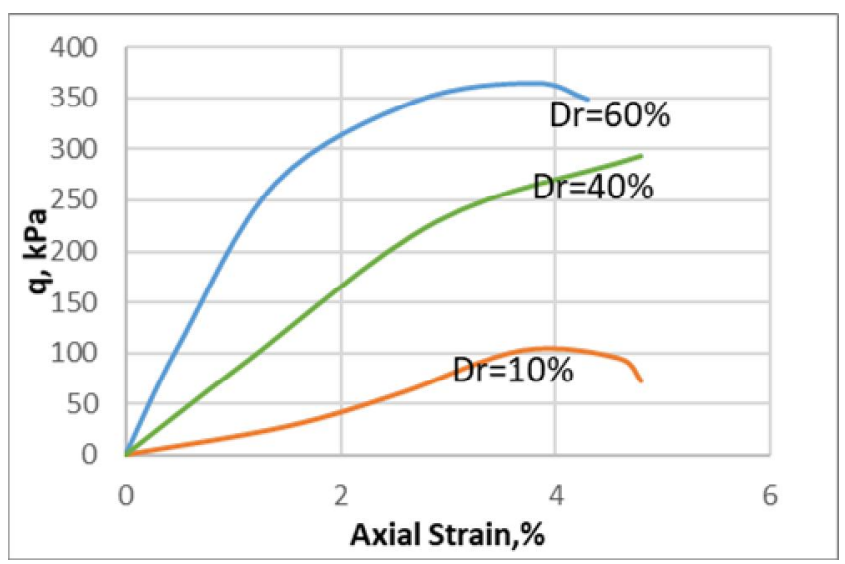

Figure 3: Deviatoric stress under 100kPa confining pressure, $\mathrm{FA}=10 \%$

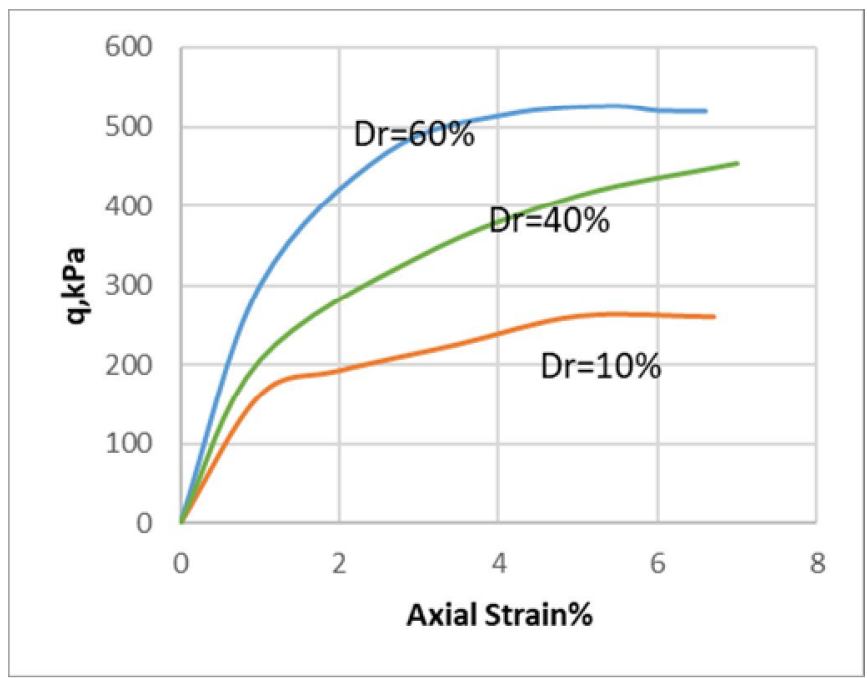

Figure 4: Deviatoric stress under 150kPa confining pressure $\mathrm{FA}=10 \%$ 
Amin Chegenizadeh et al., International Journal of Emerging Trends in Engineering Research, 8(4), April 2020, 1259 - 1263

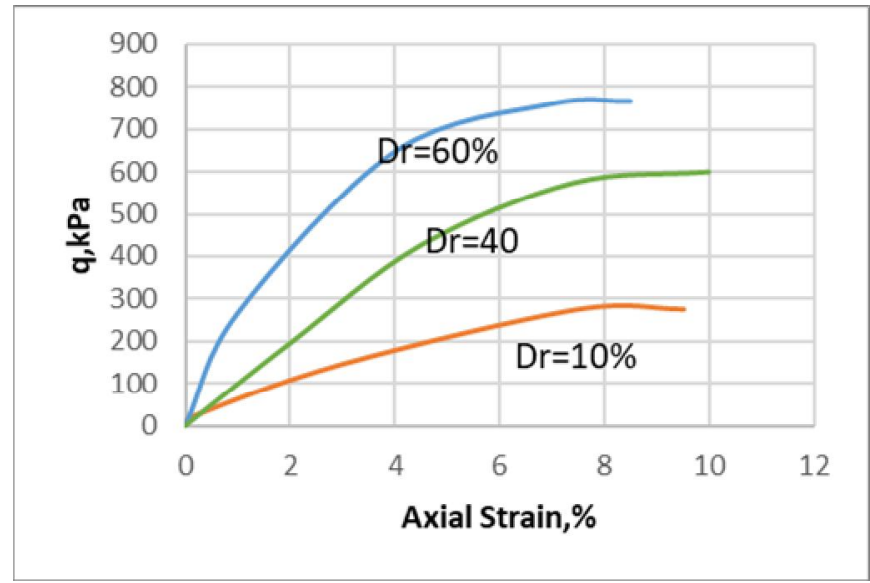

Figure 5: Deviatoric stress under 200kPa confining pressure $\mathrm{FA}=10 \%$

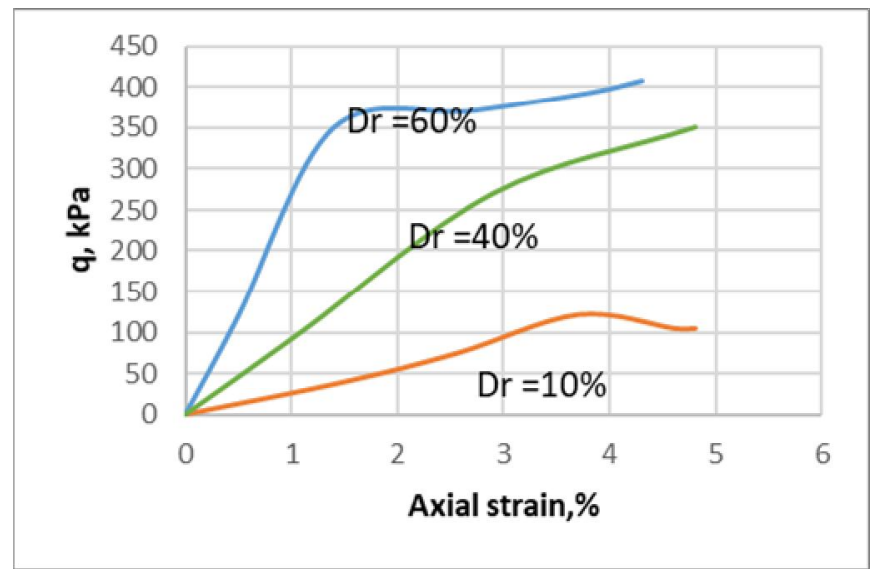

Figure 6: Deviatoric stress under 100kPa confining pressure, $\mathrm{FA}=15 \%$

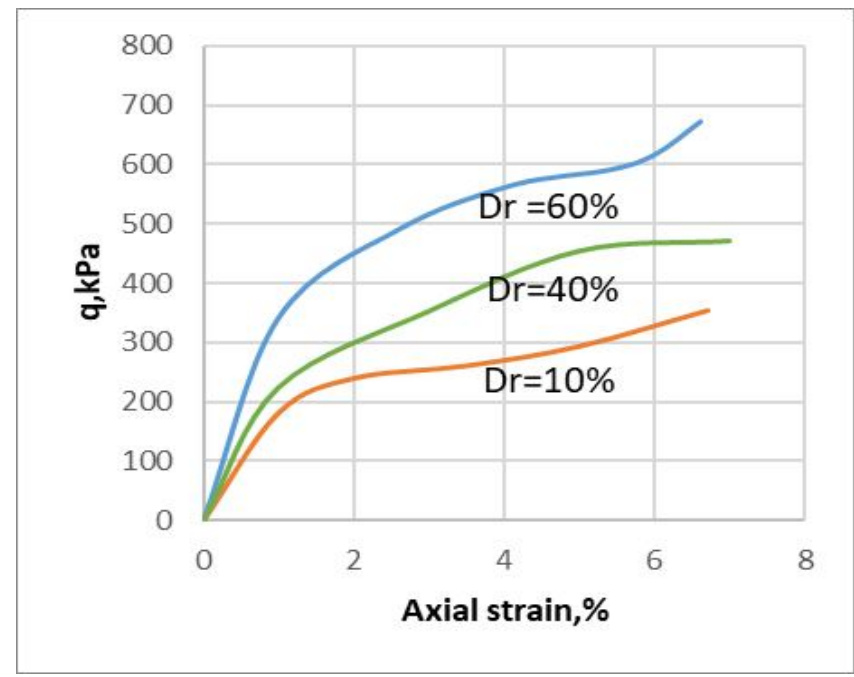

Figure 7: Deviatoric stress under $150 \mathrm{kPa}$ confining pressure, $\mathrm{FA}=15 \%$

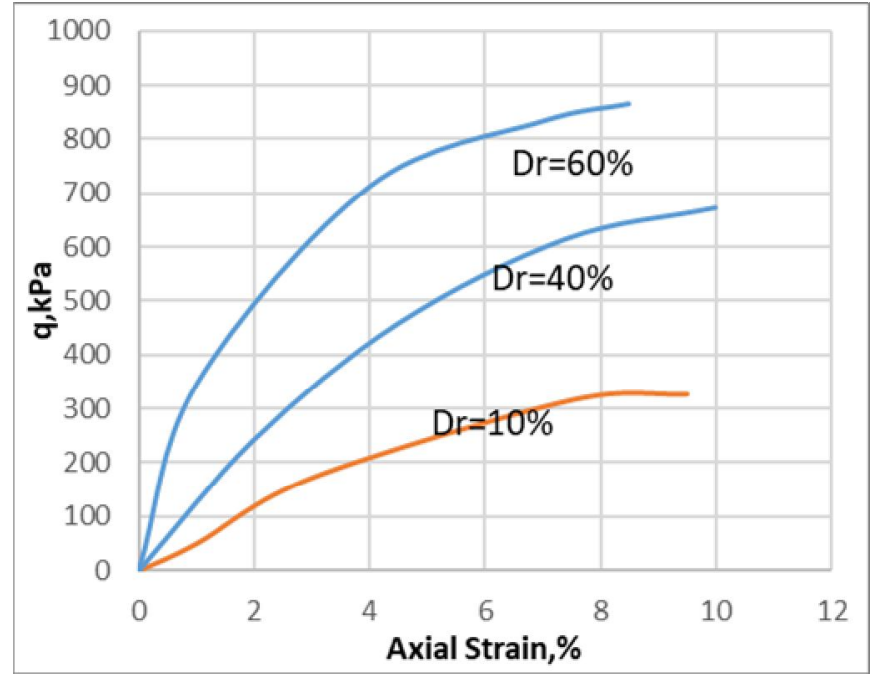

Figure 8: Deviatoric stress under 200kPa confining pressure, $\mathrm{FA}=15 \%$

\section{CONCLUSION}

A series of triaxial tests were conducted on a mixture. The mixture was combination of flyash, sand and fiber. The results proved that:

a) The MDD of compaction decreased by increasing in flyash dosage.

b) $\mathrm{OMC}$ was increased due to inclusion of flyash.

c) The increase in Dr from 10 to $40 \%$ in all confining pressure of 100,150 and $200 \mathrm{kPa}$, showed increment in .q.

d) Flyash changed from 10 to $15 \%$, similar trend was observed with effect of Dr on diviatoric stresses.

\section{REFERENCES}

[1] Al-rkaby, A.H.J., Chegenizadeh, A., Nikraz, H.R. 2017 Cyclic behavior of reinforced sand under principal stress rotation Journal of Rock Mechanics and Geotechnical Engineering 9(4), pp. 585-598 https://doi.org/10.1016/j.jrmge.2017.03.010

[2] Al-Rkaby AHJ, Chegenizadeh A, Nikraz H. Directional-dependence in the mechanical characteristics of sand: a Review International Journal of Geotechnical Engineering 2016. 10 (5), 499-509

[3] Keramatikerman M, Chegenizadeh A. Effect of particle shape on monotonic liquefaction: Natural and crushed sand. Experimental Mechanics. 2017 Oct 1;57(8):1341-8.

https://doi.org/10.1007/s11340-017-0313-Z 
[4] Chegenizadeh A, Ghadimi B, Nikraz H, Simsek M. A novel two-dimensional approach to modelling functionally graded beams resting on a soil medium. Structural Engineering and Mechanics. 2014;51(5):727-41

[5] Habibbeygi, F., Nikraz, H., Chegenizadeh, A. Intrinsic compression characteristics of an expansive clay from Western Australia International Journal of GEOMATE 2017,12(29), pp. 140-147 https://doi.org/10.21660/2017.29.20455

[6] Lazaratou, C.V., D.V. Vayenas, and D. Papoulis, The role of clays, clay minerals and clay-based materials for nitrate removal from water systems: A review. Applied Clay Science, 2020. 185: p. 105377.

[7] Selonen, S., et al., Exploring the impacts of plastics in soil - The effects of polyester textile fibers on soil invertebrates. Science of The Total Environment, 2020. 700: p. 134451.

[8] Chegenizadeh, A., Nikraz, $H$ Investigation on compaction characteristics of reinforced soil .

Advanced Materials Research 2011, 261-263, pp. 964-968

[9]Rajesh Kumar, K., et al., Free thaw resistance of stabilized and fiber-reinforced soil vulnerable to landslides. Materials Today: Proceedings, 2020. https://doi.org/10.1016/j.matpr.2020.02.041

[10] Chegenizadeh, A., Nikraz, H. Shear test on reinforced clay Advanced Materials Research 2011, 250-253, pp. 3223-3227

[11]Tomar, A., T. Sharma, and S. Singh, Strength properties and durability of clay soil treated with mixture of nano silica and Polypropylene fiber. Materials Today: Proceedings, 2020. https://doi.org/10.1016/j.matpr.2019.12.239

[12] Chegenizadeh, A., Nikraz, H. Investigation on strength of fiber reinforced clay Advanced Materials Research 2011.261-263, pp. 957-963.

[13]Yang, K.-H., et al., Fiber-reinforced internally unstable soil against suffusion failure. Construction and Building Materials, 2019. 222: p. 458-473.

[14] Chegenizadeh, A. and H. Nikraz, Composite Soil: Fiber Inclusion and Strength, Journal of Advanced Materials Research 2011.1646

[15] Chegenizadeh, A. and H. Nikraz,Study on modulus of elasticity of reinforced clay, Advanced Materials Research. 2011.243-249: pp. 5885-5889, 2011.

[16]Tran, K.Q., T. Satomi, and H. Takahashi, Tensile behaviors of natural fiber and cement reinforced soil subjected to direct tensile test. Journal of Building Engineering, 2019. 24: p. 100748.

[17] Chegenizadeh A, Nikraz H. Permeability test on reinforced clayey sand. World Academy of Science, Engineering and Technology. 2011;54:130-3.

[18]Li, Y., et al., Tensile strength of fiber reinforced soil under freeze-thaw condition. Cold Regions Science and Technology, 2018. 146: p. 53-59.
[19] Chegenizadeh, A. and H. Nikraz, Composite Clayey Sand and Short Fiber, Advanced Materials Research 2012.383, 2764-2769

[20] Yang K-H, Wei S-B, Adilehou WM, Ho H-C. Fiber-reinforced internally unstable soil against suffusion failure. Construction and Building Materials. 2019;222:458-73.

[21] Chegenizadeh, A., Keramatikerman, M., \& Nikraz, H. Liquefaction resistance of fibre reinforced low-plasticity silt. Soil Dynamics and Earthquake Engineering,2018. 104, 372-377.

https://doi.org/10.1016/j.soildyn.2017.11.004

[22] Keramatikerman, M., Chegenizadeh, A., \& Nikraz, H. An investigation into effect of sawdust treatment on permeability and compressibility of soil-bentonite slurry cut-off wall. Journal of Cleaner Production, 2017.162, 1-6.

[23]Kafodya, I. and F. Okonta, Effects of natural fiber inclusions and pre-compression on the strength properties of lime-fly ash stabilised soil. Construction and Building Materials, 2018. 170: p. 737-746.

[24] Al-Rkaby AHJ, Chegenizadeh A, Nikraz H. Anisotropic strength of large scale geogrid-reinforced sand:experimental study Soils and foundations 2017.57 (4), 557-574

[26]Arulrajah, A., et al., Strength and microstructure evaluation of recycled glass-fly ash geopolymer as low-carbon masonry units. Construction and Building Materials, 2016. 114: p. 400-406.

[27] Sabbar AS, Chegenizadeh A, Nikraz H. Static liquefaction of very loose sand-slag-bentonite mixtures. Soils and Foundations. 2017 Jun 1;57(3):341-56.

[28]Narayanan, A. and P. Shanmugasundaram, An Experimental Investigation on Flyash-based Geopolymer Mortar under different curing regime for Thermal Analysis. Energy and Buildings, 2017. 138: p. 539-545.

[29] Chegenizadeh, A., Keramatikerman, M., Dalla Santa, G., \& Nikraz, H. . Influence of recycled tyre amendment on the mechanical behaviour of soil-bentonite cut-off walls. Journal of cleaner production, 2018.177, 507-515

https://doi.org/10.1016/j.jclepro.2017.12.268

[30]Sharma, V.K., R.C. Singh, and R. Chaudhary, Effect of flyash particles with aluminium melt on the wear of aluminium metal matrix composites. Engineering Science and Technology, an International Journal, 2017. 20(4): p. 1318-1323.

[31]Dahale, P.P., P.B. Nagarnaik, and A.Y. Gajbhiye, Engineering Behavior of Remolded Expansive Soil with Lime and Flyash. Materials Today: Proceedings, 2017. 4(9): p. 10581-10585.

[33]Sarangi, P.K., D. Mahakur, and P.C. Mishra, Soil biochemical activity and growth response of rice Oryza sativa in flyash amended soil. Bioresource Technology, 2001. 76(3): p. 199-205. 
[34] Chegenizadeh A, Keramatikerman M, Panizza S, Nikraz H. Effect of powdered recycled tire on sulfate resistance of cemented clay. Journal of Materials in Civil Engineering. 2017 Oct 1;29(10):04017160.

[35]Kalra, N., R.C. Harit, and S.K. Sharma, Effect of flyash incorporation on soil properties of texturally variant soils. Bioresource Technology, 2000. 75(1): p. 91-93.

[36] Keramatikerman M, Chegenizadeh A, Nikraz H. Experimental study on effect of fly ash on liquefaction resistance of sand Soil Dynamics and Earthquake Engineering,2017. 93, 1-6 https://doi.org/10.1016/j.soildyn.2016.11.012

[37]Shekhawat, P., G. Sharma, and R.M. Singh, Strength behavior of alkaline activated eggshell powder and flyash geopolymer cured at ambient temperature. Construction and Building Materials, 2019. 223: p. 1112-1122.

[38] Amiralian S, Budihardjo MA, Chegenizadeh A, Nikraz $H$. Study of scale effect on strength characteristic of stabilised composite with sewage sludge-Part A: Preliminary study. Construction and Building Materials. 2015 Apr 1;80:339-45.

[39]Pandurangan, K., M. Thennavan, and A. Muthadhi, Studies on Effect of Source of Flyash on the Bond Strength of Geopolymer Concrete. Materials Today: Proceedings, 2018. 5(5, Part 2): p. 12725-12733.

[40] Hasan, U., Chegenizadeh, A., Budihardjo, M.A., Nikraz, $\mathrm{H}$ Shear strength evaluation of bentonite stabilised with recycled materials . Journal of GeoEngineering 2016 11(2), pp. 59-73

[41] Wu, J., et al., Expansive soil modified by waste steel slag and its application in subbase layer of highways. Soils and Foundations, 2019. 59(4): p. 955-965.

[42] Mahedi, M., B. Cetin, and A.Y. Dayioglu, Effect of cement incorporation on the leaching characteristics of elements from fly ash and slag treated soils. Journal of Environmental Management, 2020. 253: p. 109720.

[43] Zhang, D.-b., Y. Zhang, and T. Cheng, Measurement of grass root reinforcement for copper slag mixed soil using improved shear test apparatus and calculating formulas. Measurement, 2018. 118: p. 14-22. https://doi.org/10.1016/j.measurement.2018.01.005

[44] Shalabi, F.I., I.M. Asi, and H.Y. Qasrawi, Effect of by-product steel slag on the engineering properties of clay soils. Journal of King Saud University Engineering Sciences, 2017. 29(4): p. 394-399.

[45]Priyanga, G., K. Divya Krishnan, and P.T. Ravichandran,

Characteristics of Rubberized Soil with Ground Granulated Blast-Furnace Slag as Binder Material. Materials Today Proceedings, 2018. 5(2, Part 3): p. 8655-8661.

[46]Raghavendra T, Udayashankar BC. Engineering properties of controlled low strength materials using flyash and waste gypsum wall boards. Construction and Building Materials. 2015;101:548-57. https://doi.org/10.1016/j.conbuildmat.2015.10.070

[47] Mohd Fakri Muda, Saffuan Wan Ahmad, Fadhluhartini Muftah, Mohd Syahrul Hisyam Mohd Sani, Mechanical Behaviour of Mortar Made with Washed Bottom Ash as Sand Replacement, International Journal of Emerging Trends in Engineering Research,2019 7 (9). 